\title{
Carrying Capacity of Kedungombo Reservoir for Net Cage Culture
}

Iwan Chandra Binsar Hamonangan Simanjuntak ${ }^{*}$, and Fuad Muhammad ${ }^{2}$

${ }^{1}$ Master Program of Environmental Science, School of Post Graduate Studies, Diponegoro University - Indonesia

${ }^{2}$ Department of Biology, Faculty of Science and Mathematics, Diponegoro University, Semarang - Indonesia

\begin{abstract}
Kedungombo reservoir with an area $4.800 \mathrm{Ha}$, being a drinking and municipal water supply, power generation, flood control, and fisheries activities namely net cage culture and capture fisheries. Carrying capacity assessment of Kedungombo Reservoir was conducted in relation to change in water volume and the present of net cage culture activity. This study to estimate carrying capacity of the reservoir for the culture of net cage. Carrying capacity was analyzed using the Beveridge formula (1996). Carrying capacity of Kedungombo Reservoir with net cage culture in this research is 5.114 tons/year with 1.461 total number of net cages allowed in reservoir. The number of net cages culture currently is 3.781 plots with total fish production on net cages culture is 13.233 tons/year. Thus, the culture activity of net cage fish has exceeded the carrying capacity of the Kedungombo Reservoir.
\end{abstract}

Keywords: Carrying Capacity; Net Cage Culture; Kedungombo Reservoir.

\section{Introduction}

On Kedungombo reservoirs with an area of $4800 \mathrm{Ha}$, is a reservoir used for providers of raw drinking water, power generation, flood control, and fisheries activities namely net cage culture and fishing catch. Potential of water Reservoirs on Kedungombo comes from Serang River and Uter River, puddle on Kedungombo Reservoir area covers three areas, namely Kabupaten Grobogan administration, Sragen and Boyolali District. After the construction of the reservoir completed on Kedungombo Reservoir, the waters used for net cage culture activities.

Fish cultivation activites at the Kedungombo Reservoir experienced quite rapid development. The year 2012, the number of net cage culture in the reservoir still 1.696 plots, but in July 2017, the number of compartments in net cages culture on Kedungombo Reservoirs has reached 3.781 plots of net cages [1]. Ease of access in the cultivation of net cage culture in the reservoir became one of the reasons the community continue to develop net cage culture, so that the total number of net cage culture found in reservoirs have exceeded the capacity of ecological reservoir [2]. Whereas the development of the net cage culture should always consider the quality and sustainability of the water reservoirs for the sustainability of the net cage culture.

Based on several studies that have been carried out in Kedungombo Reservoir, this reservoir includes the water of the eutrophic category. The Kedungombo reservoir are categorized as eutrophic from a low brightness value i.e. $55-118 \mathrm{~cm}$, total nitrogen i.e. 0,02
- 1,16 mg/L total phosphorus, i.e. $10-670 \mu \mathrm{g} / \mathrm{L}$ and high chlorophyll-a content i.e. $18,37 \mu \mathrm{g} / \mathrm{L}[3,4]$. Eutrophication is the process of nutrient enriched because the supply of organic material from human activity or natural, which is charaterized by high concentration of total-P, total-N and chlorophyll-a [5]. Human activities that cause elements of phosphorus and nitrogen into the waters among others derived from detergents, the use of fertilizer in agriculture, and the cultivation of net cage culture i.e. excessive residual feed and fish extretion.

Decomposition of organic matter will increase the element of phosphorus and nitrogen in the waters. Phosphorus becomes the decisive element for the growth of phytoplankton and other organisms in the waters. Large phytoplankton populations showed reservoir waters experiencing eutrophication, which will affect the level of productivity of aquaculture fishery in the reservoir [6]. The phosphorus problem in the reservoir is important than nitrogen because nitrogen is bound in the form of a sedimental organic material that must first be decomposed, whereas phosphorus is bound and accumulates in inorganic form [7].

Waters carrying capacity is the amount of fish biomass that can be produced by fish farming activities in net cages (KJA) without increasing the fertility of the waters is used as one of the considerations in the development of sustainable net cage fish cultivation in a water body. Determination of reservoir carrying capacity for fish farming activities of floating net cages helps to realize low carbon development. This is reinforced in the 2020-2024 National Medium Term Development Plan (RPJMN) which is based on

\footnotetext{
${ }^{*}$ Corresponding author: iwan7simanjuntak@gmail.com
} 
Indonesia's sustainable economic development, poverty alleviation and reduction of greenhouse gas (GHG) emissions. The carrying capacity of Kedungombo Reservoir needs to be established as control of phosphorus pollution in the waters towards the cultivation of net cage culture. The purpose of this research is to estimate carrying capacity of the reservoir for the culture of net cage.

\section{Materials and methods}

\subsection{Research Area}

Kedungombo Reservoir, Sumberlawang Subdistrict, Sragen Regency, Central Java, Indonesia became the research location for carrying capacity for floating net cage fish cultivation. (Figure 1).

\subsection{Procedures}

\subsubsection{Water Quality and Laboratory Test}

Water quality of reservoir parameters being measured include temperature, $\mathrm{pH}, \mathrm{DO}, \mathrm{BOD}, \mathrm{COD}$, TSS, total-P and total-N. To analyze the Kedungombo Reservoir water quality, nine water samples were taken at two water depths, i.e. surface water and from the bottom of reservoir at five sampling sites (Table. 1). The water samples were taken on Mei, 2018 using a vertical water sampler and brought to the laboratory on the following day. Selected physical and a chemical parameters were analyzed and compared to national water quality standars class II based on Government Regulation No. $82,2001$.

Table 1. The coordinates of water sampling points at Kedungombo Reservoir

\begin{tabular}{|c|c|}
\hline Sampling sites & Location cordinates \\
\hline Point 1, Serang River & $7^{\circ} 17^{\prime} 15,544^{\prime \prime} \mathrm{S}-110^{\circ} 42^{\prime}$ \\
& $40,86^{\prime \prime} \mathrm{E}$ \\
\hline Point 2, middle reservoir & $7^{\circ} 15^{\prime} 35,58^{\prime \prime} \mathrm{S}-110^{\circ} 50^{\prime}$ \\
& $1,92^{\prime}, \mathrm{E}$ \\
\hline Point 3, net cage of & $7^{\circ} 16^{\prime} 40,744^{\prime \prime} \mathrm{S}-110^{\circ} 49^{\prime}$ \\
Aquafarm & $37,38^{\prime \prime} \mathrm{E}$ \\
\hline Point 4, outlet of reservoir & $7^{\circ} 15^{\prime} 27,244^{\prime \prime} \mathrm{S}-110^{\circ} 50^{\prime}$ \\
& $4,08^{\prime}, \mathrm{E}$ \\
\hline Point 5, net cage of & $7^{\circ} 17^{\prime} 58,74^{\prime \prime} \mathrm{S}-110^{\circ} 49^{\prime}$ \\
Ngasinan & $27,844^{\prime} \mathrm{E}$ \\
\hline
\end{tabular}

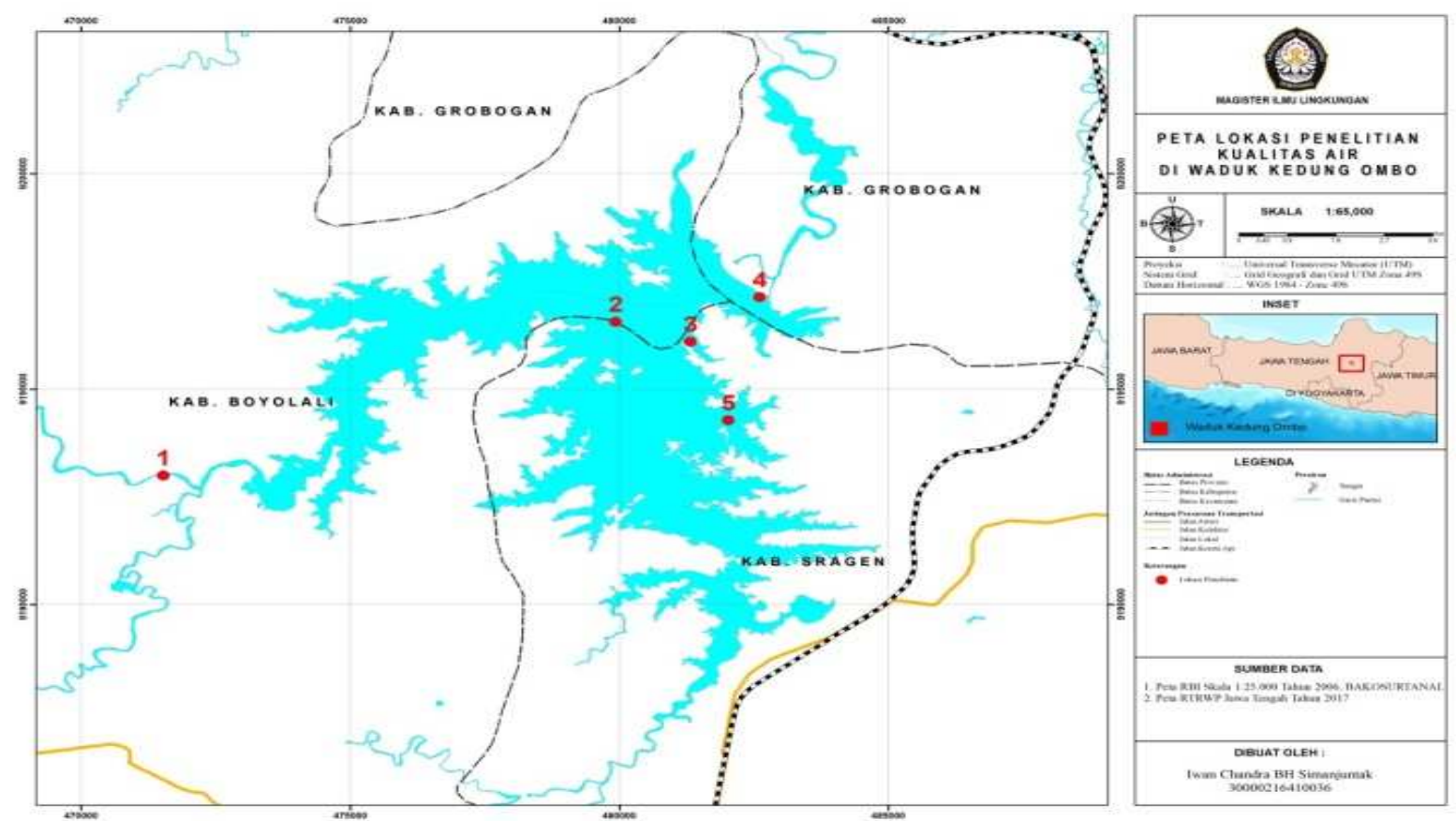

Fig 1. Research location and water sampling points atKedungombo Reservoir, Sragen, Indonesia 


\subsection{Data Analysis}

\subsubsection{Carrying Capacity of Kedungombo Reservoir}

Analysis of carrying capacity for the net cage culture is calculated by the Beveridge (1996) formula, the steps are as follows:

1. Morphology and Hydrology of Reservoirs

$$
\begin{aligned}
& \mathrm{Z}=\mathrm{V} / \mathrm{A} \\
& \rho=\mathrm{Q} / \mathrm{V}
\end{aligned}
$$

Explanation:

$\mathrm{Z}$ : Average depth of reservoir (m)

$\mathrm{V}$ : Volume of reservoir (million $\mathrm{m}^{3}$ )

A : Area of reservoir $(\mathrm{Ha})$

$\rho:$ Rate of water change of reservoir (per year)

$\mathrm{Q}$ : Number of discharge water reservoirs out (million $\mathrm{m}^{3} /$ year)

2. Phosphorus Pollution Load Allocation (P)

$$
\Delta[\mathrm{P}]=[\mathrm{P}] \mathrm{f}-[\mathrm{P}] \mathrm{i}
$$

Explanation:

$\Delta[\mathrm{P}]$ : Total-P allocation of fish farming $\left(\mathrm{mg} / \mathrm{m}^{3}\right)$

$[\mathrm{P}]_{\mathrm{f}}$ : Maximum Total-P kada conditions in accordance with water quality standard or water class $\left(\mathrm{mg} \mathrm{m}^{3}\right)$

$[\mathrm{P}]_{\mathrm{i}} \quad$ : Total-P parameters of monitoring results of reservoirs $\left(\mathrm{mg} / \mathrm{m}^{3}\right)$

3. Total-P Pollution Load

$$
\begin{aligned}
& \mathrm{Lfish}=\Delta[\mathrm{P}] \mathrm{Z} \rho /(1-\mathrm{R} \text { fish }) \\
& \mathrm{R}_{\text {fish }}=(1-\mathrm{x}) * \mathrm{R}+\mathrm{x} \\
& \mathrm{R}=1 \div(1+0,515 \rho 0,551) \\
& \mathrm{La}=\mathrm{L}_{\text {fish }} * \mathrm{~A}
\end{aligned}
$$

Explanation:

Lfish : Total-P fish waste capacity per unit of reservoir area $\left(\mathrm{g} / \mathrm{m}^{2} /\right.$ year $)$

La : Total capacity of Total-P fish waste in lake waters (g/year)

$\mathrm{R} \quad$ : Total-P left with sediment

$\mathrm{R}_{\mathrm{fish}}$ : The proportion of Total-P that dissolves into the sediment after the cage is present

$\mathrm{X}$ : Proportion of Total-P that is permanently entered into the base, $45-50 \%$

4. Feed and Waste P Aquaculture Net Cage

$$
P_{L P}=F C R \times P_{\text {feed }}-P_{\text {fish }}
$$

Explanation:

$\mathrm{P}_{\mathrm{LP}} \quad$ : Total $\mathrm{P}$ entering the reservoir from the fish waste $(\mathrm{kg} / \mathrm{tonne}$ of fish)

FCR : Feed Convertion Ratio (ton/ton feed fish)

$\mathrm{P}_{\text {feed }} \quad$ : Total-P Levels in the feed $(\mathrm{kg} / \mathrm{ton}$ feed)

$\mathrm{P}_{\text {fish }} \quad$ : Total Levels $-\mathrm{P}$ in fish $(\mathrm{kg} / \mathrm{tonne}$ of fish)

5. Number of Aquaculture

$$
\begin{aligned}
& \mathrm{LI}=\mathrm{La} / \mathrm{P}_{\mathrm{LP}} \\
& \mathrm{LP}=\mathrm{LI} \times \mathrm{FCR}
\end{aligned}
$$

Explanation:

LI : Total production of net cage culture (tons of fish/year)

LP : Total feed of net cage culture (ton of feed/year)

6. Determination of Net Cage

The Ideal number of cages $=$ LI $/$ Total fish production per year on net cages

Number of cages to be reduced $=$ Total number of existing net cages - The ideal number of cages (12)

\section{Result and Discussion}

\subsection{Status of Water Quality}

Fish culture using floating nets in the Kedungombo Reservoir uses a size of $7 \times 7 \mathrm{~m}$. The types of fish that are the mainstay of floating net cage cultivation in Kedungombo Reservoir are tilapia and tombro (mas) fish.Water quality is the most important part in cultivation activities. Decrease in water quality will lead to inhibition of fish growth, stress on fish, and trigger the development of fish diseases [8]. Table 2 shows that the water quality sample measured in this study was taken on the surface of the reservoir water body (L) and the bottom of the reservoir waters (i). Results of temperature measurement, TSS and $\mathrm{pH}$ are still in accordance with the quality standard of Government Regulation No. 82 of 2001, Class II. BOD measurements at each point ranged from 5,99 to 59,38 $\mathrm{mg} / \mathrm{L}$, COD values ranged from 13,52 to $98,11 \mathrm{mg} / \mathrm{L}$, DO values ranged from 3,761 to $7,52 \mathrm{mg} / \mathrm{L}$ (Table. 2 ). The BOD and COD values at each point have exceeded the threshold value for class II, while for DO values at each point it still matches the standard value of Government Regulation No. 82 of 2001, class 2 is 4 $\mathrm{mg} / \mathrm{L}$. 
Table 2. Water Quality of Kedungombo Reservoir

\begin{tabular}{|c|c|c|c|c|c|c|c|c|c|c|c|c|}
\hline $\begin{array}{l}\text { Indica } \\
\text { tor }\end{array}$ & Parameter & Unit & Class II & $1 \mathrm{~L}$ & $2 \mathrm{~L}$ & $2 \mathrm{i}$ & $3 \mathrm{~L}$ & $3 \mathrm{i}$ & $4 \mathrm{~L}$ & $4 \mathrm{i}$ & $5 \mathrm{~L}$ & $5 \mathrm{i}$ \\
\hline \multirow[t]{3}{*}{$\begin{array}{c}\text { Physi } \\
\text { cal }\end{array}$} & $\begin{array}{c}\text { Temperat } \\
\text { ure }\end{array}$ & ${ }^{\circ} \mathrm{C}$ & Dev 3 & 27 & 30,6 & 29,6 & 31,1 & 29,2 & 25 & 25 & 31,5 & 30,8 \\
\hline & TSS & $\mathrm{mg} / \mathrm{L}$ & 50 & 19 & 13,33 & 11,5 & 8 & 7,2 & 5,5 & 10 & 16 & 6,4 \\
\hline & $\mathrm{pH}$ & - & $6-9$ & 7,98 & 7,52 & 7,11 & 7,5 & 7,06 & 7,4 & 7,14 & 7,61 & 7,03 \\
\hline \multirow{5}{*}{$\begin{array}{l}\text { Inorg } \\
\text { anic } \\
\text { chemi } \\
\text { cal }\end{array}$} & BOD & $\mathrm{mg} / \mathrm{L}$ & 3 & 5,99 & 17,99 & 53,98 & 33,98 & 6,8 & 29,98 & 17,99 & 10,8 & 15 \\
\hline & COD & $\mathrm{mg} / \mathrm{L}$ & 25 & 38,14 & 33,98 & 98,11 & 58,59 & 13,52 & 50,62 & 34,32 & $\begin{array}{c}21,6 \\
6\end{array}$ & 28,08 \\
\hline & DO & $\mathrm{mg} / \mathrm{L}$ & $\min 4$ & 7,5227 & $\begin{array}{c}7,287 \\
6\end{array}$ & $\begin{array}{c}5,171 \\
9\end{array}$ & $\begin{array}{c}7,326 \\
8\end{array}$ & $\begin{array}{c}3,839 \\
7\end{array}$ & $\begin{array}{c}6,582 \\
4\end{array}$ & 6,5043 & 7,44 & $\begin{array}{c}3,761 \\
4\end{array}$ \\
\hline & Total-P & $\mathrm{mg} / \mathrm{L}$ & ,2 & ,2558 &, 1711 &, 1167 & ,266 & ,0689 & 2207 & ,3507 & , 101 & ,4335 \\
\hline & Total-N & $\mathrm{mg} / \mathrm{L}$ & $\leq, 02$ & ,2237 & $\leq, 01$ & ,28 & $\leq, 01$ & $\leq, 01$ & $\leq, 01$ & 1,28 & ,13 & $\leq, 01$ \\
\hline
\end{tabular}

The total results of the measurement of $\mathrm{P}$ in the reservoir waters is 0,068 to $0,433 \mathrm{mg} / \mathrm{L}$, the total P-value in Serang River was $0,258 \mathrm{mg} / \mathrm{L}$, with the lowest total $\mathrm{P}$ value at point $3 \mathrm{i}$, the bottom of the reservoir located on KJA Aquafarm, while for the value the highest total $\mathrm{P}$ is at point $4 \mathrm{i}$, which is the bottom of the outlet of the Kedungombo Reservoir. The total N-measurement results at several points in the Kedungombo Reservoir from $\leq 0,01$ to $1,28 \mathrm{mg} / \mathrm{L}$, with the highest total $\mathrm{N}$ value at $4 \mathrm{i}$ (Table. 2). Phosphorus is an important factor and limiting factor in maintaining fertility in reservoirs. The main route where phosphorus can enter the aquatic environment is from floating net culture through feeding the fish [9]. High phosphorus load in the waters is caused by the number of floating net cages which are not in accordance with the reservoir carrying capacity [10]. The phosphate concentration is still acceptable by the waters in the range 0,005 to $0,2 \mathrm{mg} / \mathrm{L}$ [11], while the acceptable phosphorus value for tilapia culture in net cages is $0,025 \mathrm{mg} / \mathrm{L}$ [12]. Phosphorus plays an important role in the eutrophication process in waters. Excessive waste of phosphorus enters the waters and exceeds the capacity of pollutant loads from a reservoir, which will cause a large increase in algal populations in the waters, resulting in faster sedimentation and a deficit of dissolved oxygen at night which eventually causes mass death in fish. Mass mortality in net cages or in public waters is directly caused by a serious decrease in water quality and the emergence of algae population explosions [2]. The results of measurements of water quality at several points of the Kedungombo Reservoir that the value of BOD, COD, total $\mathrm{P}$ and total-N have exceeded the quality standard of government regulation number 82 of 2001 for class 2 .

\subsection{Carrying Capacity of Kedungombo Reservoir}

The relationship between total phosphorus and water carrying capacity is negative. The carrying capacity of Kedungombo Reservoir with the average total phosphorus concentration of $0,216 \mathrm{mg} / \mathrm{L}$ is 5.114 tons of fish/year. The cultivation of net cage in Kedungombo Reservoir uses FCR of 2 with the feed used containing phosphorus of $1,8 \%$ [13], the phosphorus waste generated from fish farming activities (PLP) is 32.600 $\mathrm{kg}$ (Table. 3). P. Generally, the feed conversion ratio used for tilapia cultivation in net cages is 1,50 . It shows that the amount of feed given by net cages culture farmers in Kedungombo Reservoir is still less efficient [12]. Excessive organic matter into the water is caused by inefficient feeding and will lead to eutrophication. Currently the number of fish culture production using net cages of 3,5 tons of fish/year x 3.781 net cages plot $=13.233$ tons of fish/year, then the current production amount of cage fishery has exceeded the limits determined based on the load capacity of phosphorus contamination.

Table 3. Result of Calculation The Carrying Capacity of Kedungombo Reservoir

\begin{tabular}{|c|c|c|c|c|}
\hline Num & Parameters & Symbol & Unit & Value \\
\hline \multirow[t]{2}{*}{1.} & \multirow{2}{*}{$\begin{array}{c}\text { Morphology and Hydrology of } \\
\text { Reservoirs }\end{array}$} & $\mathrm{Z}$ & $\mathrm{m}$ & 15 \\
\hline & & $\rho$ & per year & 1,26 \\
\hline 2. & $\begin{array}{l}\text { Phosphorus Pollution Load } \\
\text { Allocation }\end{array}$ & $\Delta[\mathrm{P}]_{\mathrm{d}}$ & $\mathrm{mg} / \mathrm{m}^{3}$ & 343 \\
\hline \multirow[t]{4}{*}{3.} & \multirow[t]{4}{*}{ Total-P Pollution Load } & $\mathrm{L}_{\text {fish }}$ & $\mathrm{g} / \mathrm{m}^{2} /$ year & 3,4735 \\
\hline & & $\mathrm{R}_{\text {fish }}$ & - & 0,815 \\
\hline & & $\mathrm{R}$ & - & 0,63 \\
\hline & & $\mathrm{La}$ & g/year & $166,728 \times 10^{6}$ \\
\hline \multirow[t]{2}{*}{4.} & \multirow{2}{*}{$\begin{array}{c}\text { Feed and Waste P Aquaculture } \\
\text { Net Cage }\end{array}$} & $P_{L P}$ & $\mathrm{~kg} /$ tonne of fish & 32,6 \\
\hline & & FCR & tons feed/tons fish & 2 \\
\hline \multirow[t]{2}{*}{5.} & \multirow[t]{2}{*}{ Number of Aquaculture } & LI & tons fish/year & 5.114 \\
\hline & & LP & ton feed/year & 10.228 \\
\hline
\end{tabular}


The number of nets currently in the Kedungombo Reservoir at the time of the study was 3,781 net net plots. The ideal number of cages for a size of $7 \times 7 \mathrm{~m}$ according to the carrying capacity of the Kedungombo Reservoir is 1.461 plots or the extent of $71.589 \mathrm{~m}^{2}(0,15 \%$ of the reservoir area). With the total number of net cages based on the Department of Animal Husbandry and Fisheries of Sragen Regency until July 2017 the data is 3,781 plots with $185.279 \mathrm{~m} 2(0,39 \%$ of the reservoir area. The current number has exceeded the reservoir carrying capacity, and the number of cages that have to be reduced is 2.320 plots. According to the Central Java Central Bureau of Water Management (BPSDA), in general the land in the lake or reservoir is set by the government $1-2 \%$, depending on the provisions of the local government. However, this provision must be reviewed because the number of floating net cages in the Kedungombo Reservoir has exceeded the allowed carrying capacity. Current carrying capacity calculation is an indication of momentary carrying capacity. In order for floating net cage cultivation to be sustainable and in accordance with the reservoir carrying capacity, what needs to be done is to reduce floating net cages, use double nets, efficiently feed fish and reduce fish density.

\section{Conclusion}

The ideal number of $7 \times 7 \mathrm{~m}$ cage units in Kedungombo Reservoir is 1.461 plots or $71.589 \mathrm{~m} 2$ $(0,15 \%$ of reservoir area) with fish production 5.114 tons/year. Currently, the total net cage culture in Kedungombo Reservoir is 3.781 plots or 185.269 $\mathrm{m} 2(0,39 \%$ of the reservoir area) with total fish production of 13.233 tons/year, the net cage culture has exceeded the carrying capacity of the reservoir. Thus the number of net cage culture to be reduced to match the carrying capacity of the reservoir is 2.320 plots or $113.680 \mathrm{~m} 2$. The carrying capacity of phosphorus contamination for net cage culture in
Kedungombo Reservoir based on Beveridge (1996) formula is $166,728 \times 106$ gram per year. This value indicates the optimal amount of load that can be reached by the current Kedungombo Reservoir.

\section{References}

1. Dinas Peternakan dan Perikanan Sragen, Profil Waduk Kedungombo Sentra Perikanan Kab. Sragen. (2017)

2. Siagian, M., J. Perikanan dan Ilmu Kelautan. 15, 145-160 (2010)

3. Aida, S.N., Utomo, A.D., J. Bawal. 4, 59-66 (2012)

4. Hidayah, T., Ridho, M.R., dan Suheryanto, J. Maspari. 6, 104-112 (2014)

5. Redy, M. V., Restoration and Management of Tropical Eutrophic Lakes (Science Publisher, 2005)

6. Umar, C., Prosiding Seminar Nasional Biologi UGM, "Persepektif Biologi Dalam Pengelolaan Sumberdaya Hayati”. 927-935 (2010)

7. Sondergaard, M., Nutrient Dynamics in LakesWith Emphasis on Phosporus, Sediment and Lake Restoration (Doctor's Dissertation, Univ. of Aarhus, 2007)

8. Arulampalam, P., Yusoff, F.M., Shariff, M., Law, A.T., and Rao, P. S. S., J. Aquac. Res. 29, 617-624 (1998)

9. Gavine, F.M., Phillips, M.J., and Murray, A., J. Aquac. Res. 26, 483-495 (1995)

10. Mallasen, M., Barros, H.P. de, Traficante, D.P., and Camargo, A.L.S., J. Acta Sci. Biol. Sci. 34, 289-296 (2012)

11. Boyd, C.E., Water Quality for Pond Aquaculture. (Alabama Agricultural Experiment Station, Auburn University, 1998)

12. Santos, D. M. S., Cruz, C. F., Pereira, D. P., Alves, L. M. C., and Moraes, F. R. de., J. Acta Sci. Biol. Sci. 34, 199-205 (2012)

13. M. C. M. Beveridge. Cage Aquaculture. (Fishing News Books LTD, England, 1996) 